\title{
BCOR wt Allele
}

National Cancer Institute

\section{Source}

National Cancer Institute. BCOR wt Allele. NCI Thesaurus. Code C101092.

Human BCOR wild-type allele is located in the vicinity of Xp11.4 and is approximately 128

$\mathrm{kb}$ in length. This allele, which encodes BCL-6 corepressor protein, is involved in

transcriptional regulation. Mutation of the gene is associated with microphthalmia syndromic type 2 . 